\title{
Preliminary geologic, geomorphologic and geophysical studies for the paleoseismological analysis of the Amer fault (NE Spain)
}

\author{
J. Fleta' ${ }^{1}$, P. Santanach ${ }^{2}$, X. Goula ${ }^{1}$, P. Martínez ${ }^{1}$, B. Grellet ${ }^{3}$ \& E. Masana ${ }^{2}$ \\ 1 Institut Cartogràfic de Catalunya, Parc de Montjuïc, 08038 Barcelona, Spain. \\ E-mail: jfleta@icc.es \\ 2 Dept. Geodinàmica i Geofísica, Universitat de Barcelona, Zona Universitària de \\ Pedralbes, 08028 Barcelona, Spain \\ 3 Geo-Ter S.A.R.L. 3, rue Jean Monnet, 34830 Clapiers, France
}

Manuscript received: December 1997; accepted in revised form: December 1999

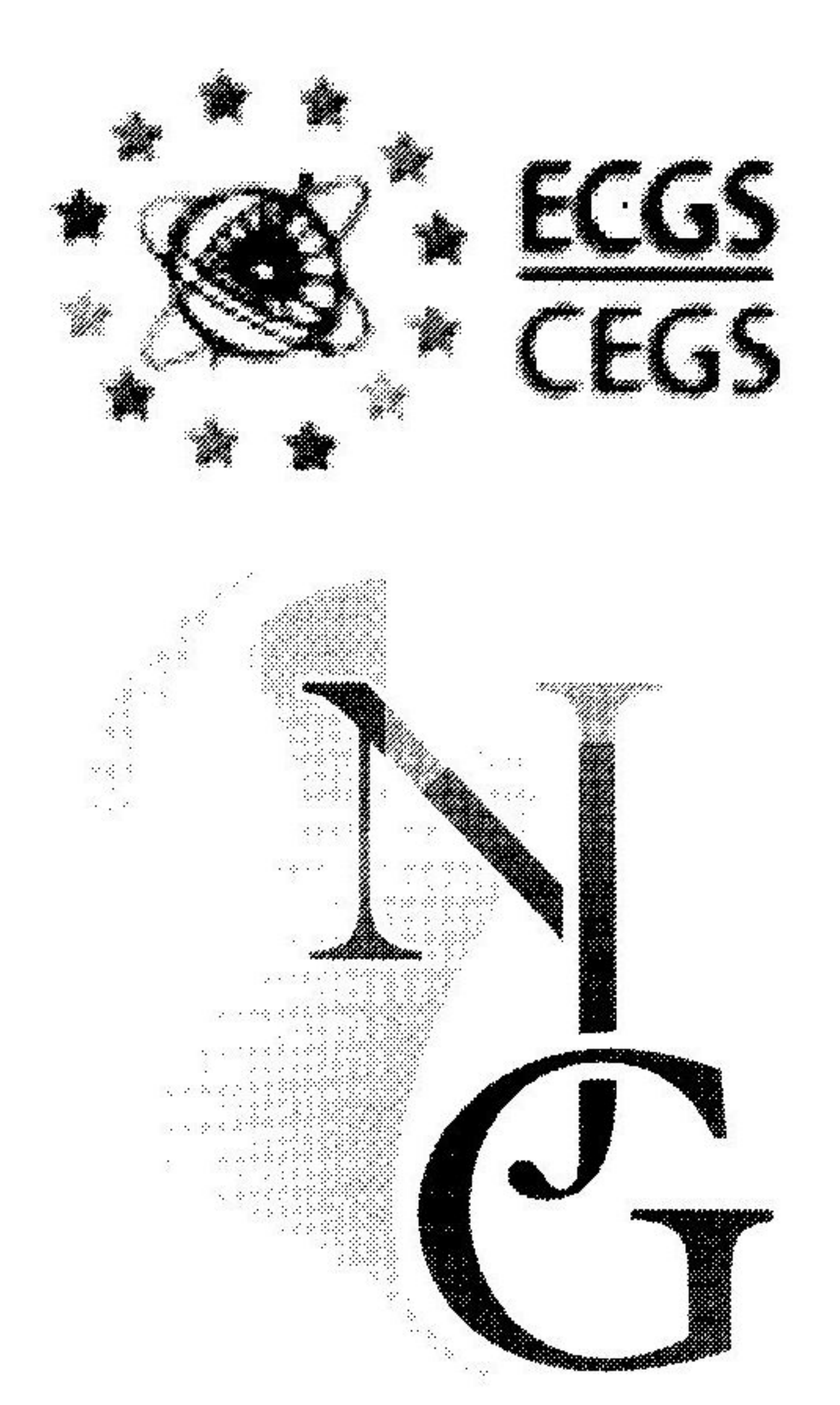

\begin{abstract}
The Amer fault is a $30 \mathrm{~km}$ long normal fault, which generated the damaging earthquakes of March and May 1427. Triangular facets, wine glass drainage basins, alluvial fans and scarps along the Amer fault mountain front provide evidence of its recent activity. Topographic profiling, electrical logging, tomographic and high-resolution seismic profiling along the northern segment of the Amer fault showed the following: i) no evidence of surface deformation in recent deposits; ii) fault scarps produced by the Amer fault located only on old alluvial fans, probably Pleistocene in age, and iii) Amer fault related deformation reaching upper Quaternary levels, but not the uppermost horizons. The high sedimentation rate (nearly one order of magnitude greater than the fault slip rate) due to the filling of the lake, which resulted from the damming of the Fluvià river by the Bosc de Tosca lava flow (17,000 yr BP), can account for the absence of surface deformation on Holocene sediments.
\end{abstract}

Keywords: Active faulting, Geomorphology, Geophysical prospecting, Earthquakes, Eastern Pyrenees

\section{Introduction}

In the Amer area, a geological and geophysical study of one fault showing geomorphologic evidence of active tectonics was performed (Paleosis EC project) in an attempt to improve our understanding of the distribution of present deformation in the eastern Pyrenees. The aim of this study was to provide evidence of Holocene surface ruptures caused by earthquakes, similar to or greater than the earthquakes that occurred during the seismic series of 1427. After a brief description of the seismotectonics of the region and of the vicinity of the Amer fault, the geomorphologic, topographical, geological and geophysical results obtained are presented. The relationship between sedimentation and fault slip rates in detecting surface ruptures is discussed.

\section{Seismotectonic framework}

Despite the moderate seismicity of the eastern Pyrenees, a destructive seismic crisis occurred in the Middle Ages (1427-1428), suggesting that periods of low seismic activity are interrupted by destructive earthquakes, probably with long recurrence intervals. Multidisciplinary research is necessary to determine the distribution and importance of the current tectonic deformations. To this end, the Servei Geològic de Catalunya (Institut Cartogràfic de Catalunya) in collaboration with different institutions commenced a study in the eastern Pyrenees in 1990. Seismicity was monitored by the Catalan seismic network (ICC, 1999a). An inventory of recent deformations was carried out, showing a regional stress regime characterized by a N-S oriented maximum compression (Goula et al., 1999). The analysis of ancient leveling 
surveys denotes the presence of anomalies of possible tectonic origin (Giménez et al., 1996). The present deformation has been monitored by a number of GPS measuring surveys since 1992 (Goula et al., 1996; Talaya et al., 1999) and no significant deformation has been measured to date.

The Amer fault (Fig. 1) is over $30 \mathrm{~km}$ long but only two small parts of the fault ruptured during the 1427 earthquakes. A $10 \mathrm{~km}$ long stretch of the fault ruptured close to Amer during the March sequence of 1427, and a ca $7 \mathrm{~km}$ long rupture in the vicinity of Joanetes caused the May $15^{\text {th }}$ earthquake (Olivera et al., 1999, FAUST, 2001). No scarps in the known historical primary sources are described. Nevertheless, some well-defined geomorphologic evidence of recent activity has been found along both segments of the fault (Briais et al., 1990, Ferrer et al., 1999).

Recently, field studies have focussed attention on recent deformation of post-Miocene formations across the Pyrenees (Goula et al., 1999), suggesting the presence of faults with recent activity (Fig. 1). Moreover, historical and modern high-precision leveling data have been compared to quantify recent vertical movements in NE Spain (Giménez et al., 1996). The magnitude of the vertical movements has been calculated by comparing the original height differences between points measured in the field in two surveys carried out by the Instituto Geográfico $\mathrm{Na}$ cional. Anomaly A $(2.5 \mathrm{~mm} / \mathrm{yr})$ and anomaly B (3 $\mathrm{mm} / \mathrm{yr}$ ) located at the ends of the Amer fault (Giménez et al., 1996) are especially relevant (Fig. 1). The Barcelona-Figueres line, which corresponds to the railway line via Mataró, was leveled in 1914-1915, 1952 and 1964. The sinking of the Selva basin of 2.5 $\mathrm{mm} / \mathrm{yr}$ (anomaly A) could be of tectonic origin. The Vic-Figueres line, which runs along the road, was leveled in 1891 and 1906; the profile shows an anomaly of $3 \mathrm{~mm} / \mathrm{yr}$ (B), which could be of tectonic origin. This anomaly indicates the sinking of the eastern block, and is placed at the northern end of the Amer fault.

\section{Preliminary studies for a paleoseismologic analysis}

Geologic, geomorphologic and geophysical studies were undertaken to select the most suitable sites to investigate the paleoseismology of the Amer fault. These preliminary studies are part of the PALEOSIS project (PALEOSIS, 1999), which deals with the ar-

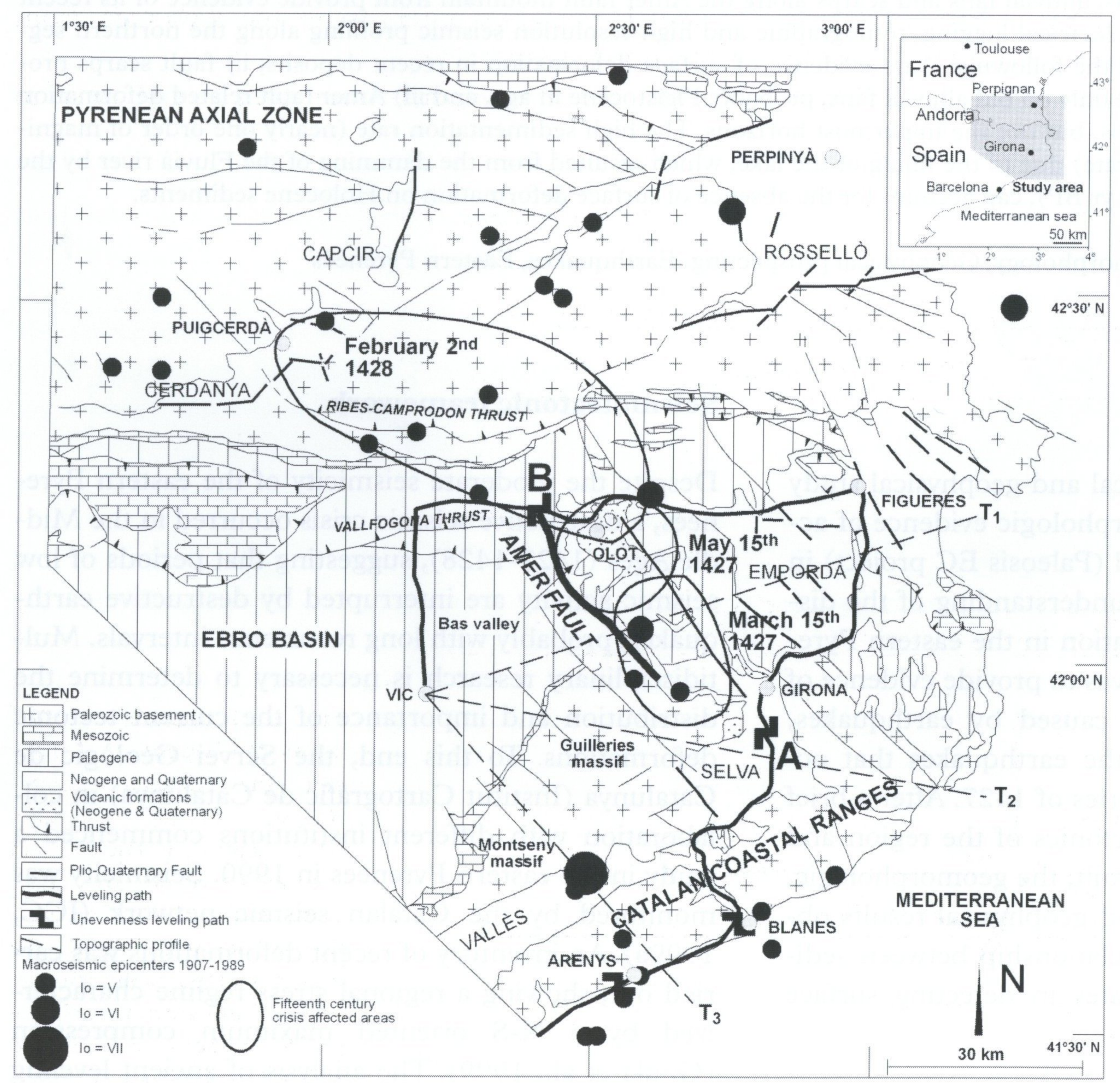

Fig. 1. Seismotectonic scheme of the Eastern Pyrenees with location of the Amer fault, indicating: i) Geologic framework showing Plio-Quaternary faults. ii) Twentieth century seismicity, and the most damaged areas caused by fifteenth century earthquakes. iii) Main recent vertical movement anomalies indicated by capital letters along leveling paths (Giménez et al., 1996) with a value of 2.5 $\mathrm{mm} / \mathrm{yr}$ (anomaly A) and 3 $\mathrm{mm} / \mathrm{yr}$ (anomaly B). iv) $\mathrm{T}$ indicates the traces of topographic profiles of Fig. 2 (Lewis et al., 2000). 
eas of Western Europe showing moderate seismicity (Fleta and Goula, 1998; Fleta et al., 1999).

\section{Geology and geomorphology}

The Amer fault is a Late Neogene NW-SE trending normal fault and is one of the westernmost faults in the fault system related to the Empordà Neogene basin (Fig. 1). The fault plane dips $60^{\circ}$ to the east and the average throw vary between 1,000 and $1,400 \mathrm{~m}$ (Saula et al., 1996). The Amer fault is located in an area where erosion has been dominant during its activity. A number of small alluvial fans were formed at the foot of the mountain front and covered the fault trace. The geological field study enabled the identification of the fault trace on the Eocene outcrops, facilitating information on its location under the Quaternary sediments.

Two arguments support the view that the Amer fault shows more recent tectonic activity than the other parallel faults of the system: (1) the migration of volcanism towards the west since the Late Miocene; this volcanism is Late Miocene in the Empordà Neogene basin, whereas the last lava flow, related to the Amer fault in the west is dated to ca $10,000 \mathrm{yrs}$ old (Guérin et al., 1986); and (2) the analysis of topographic profiles showing that the distance between the water divide and the fault trace across the Amer fault ( $\mathrm{T} 1$ profile in Fig. 1) is smaller than on $\mathrm{T}_{2}$ and
$\mathrm{T}_{3}$ profiles; this suggests a very young topography controlled by the recent activity of the Amer fault (Fig. 2) (Lewis et al., 2000).

The Amer fault consists of two segments with a slightly different strike (Figs. 3 and 4). The northern segment is $15 \mathrm{~km}$ long and the southern one is $17 \mathrm{~km}$ long. Both segments show geomorphic features, suggesting recent activity: triangular facets, wine glass shaped drainage basins and alluvial fans with possible fault scarps (Ferrer et al., 1999a).

There are at least two generations of triangular facets, the slopes of the most recent facets ranging from $17^{\circ}$ to $31^{\circ}$. The comparison of these values with those of the slopes of the triangular facets of Basin and Range -USA- (Wallace, 1978) and, in particular, with those of the Cerdanya basin -NE Spain- (Briais et al., 1990) suggests a Plio-Quaternary age for the triangular facets of the Amer fault.

The drainage pattern along the Amer fault mountain front consists of an array of wine glass drainage basins, a typical geometry related to active fronts (Fig.4). The average spacing index of the drainage basins ranges between 0.28 and 0.56 and is similar to those found in the mountain fronts of the Basin and Range (Wallace, 1978).

Along the mountain front recent small alluvial fans have their apexes upstream in the mountain front covering the Amer fault.

The southern segment runs parallel and close to
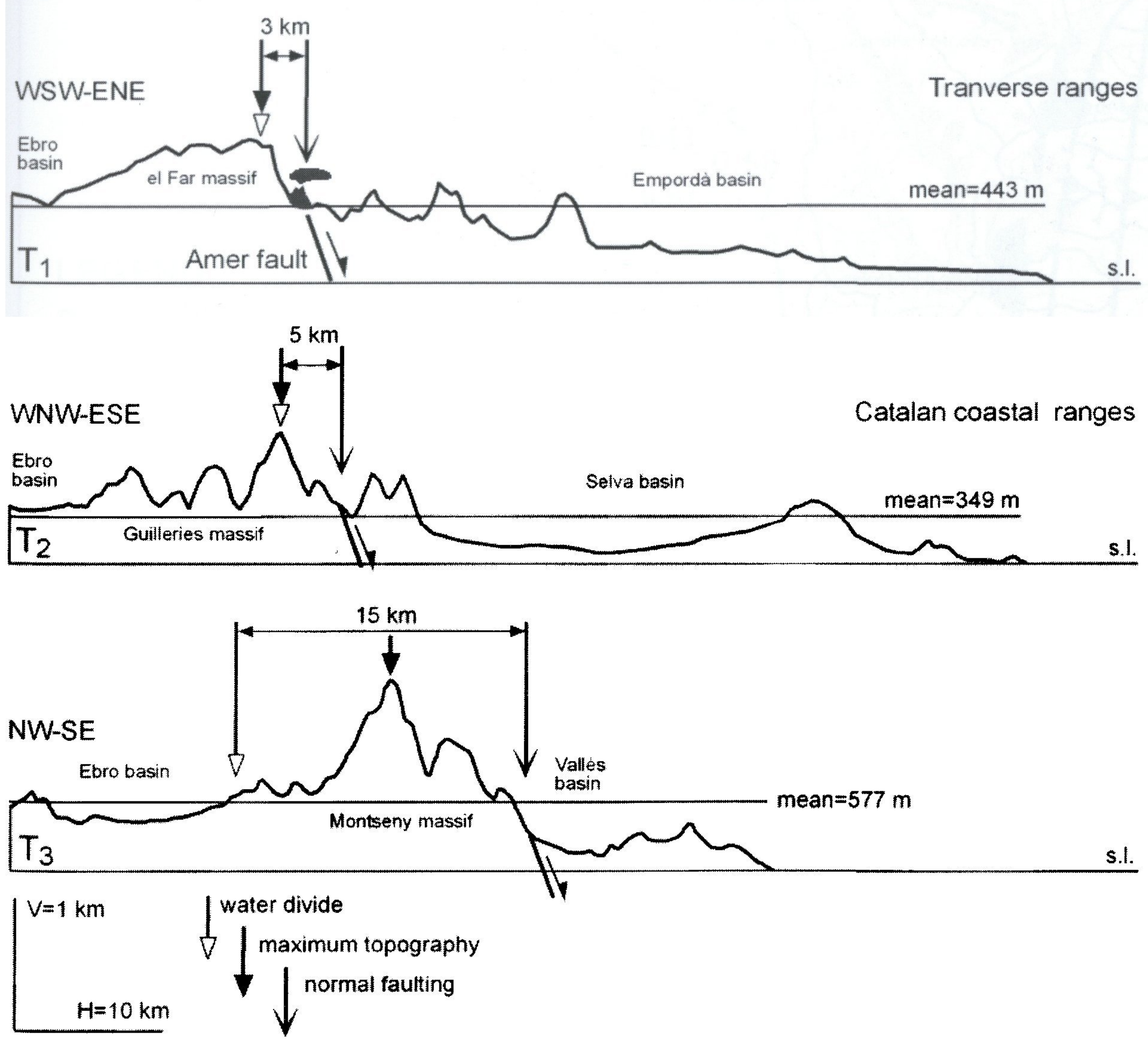

Fig. 2. Topographic profiles across the Transverse Ranges and the Catalan Coastal Ranges, showing mountain fronts separating ranges from rift basins near the coast (after Lewis et al., 2000). The location of the water divide, the maximum topography and the normal faults are indicated. The profile locations are indicated in Fig. 1 , by $T_{1}, T_{2}$ and $T_{3}$. 


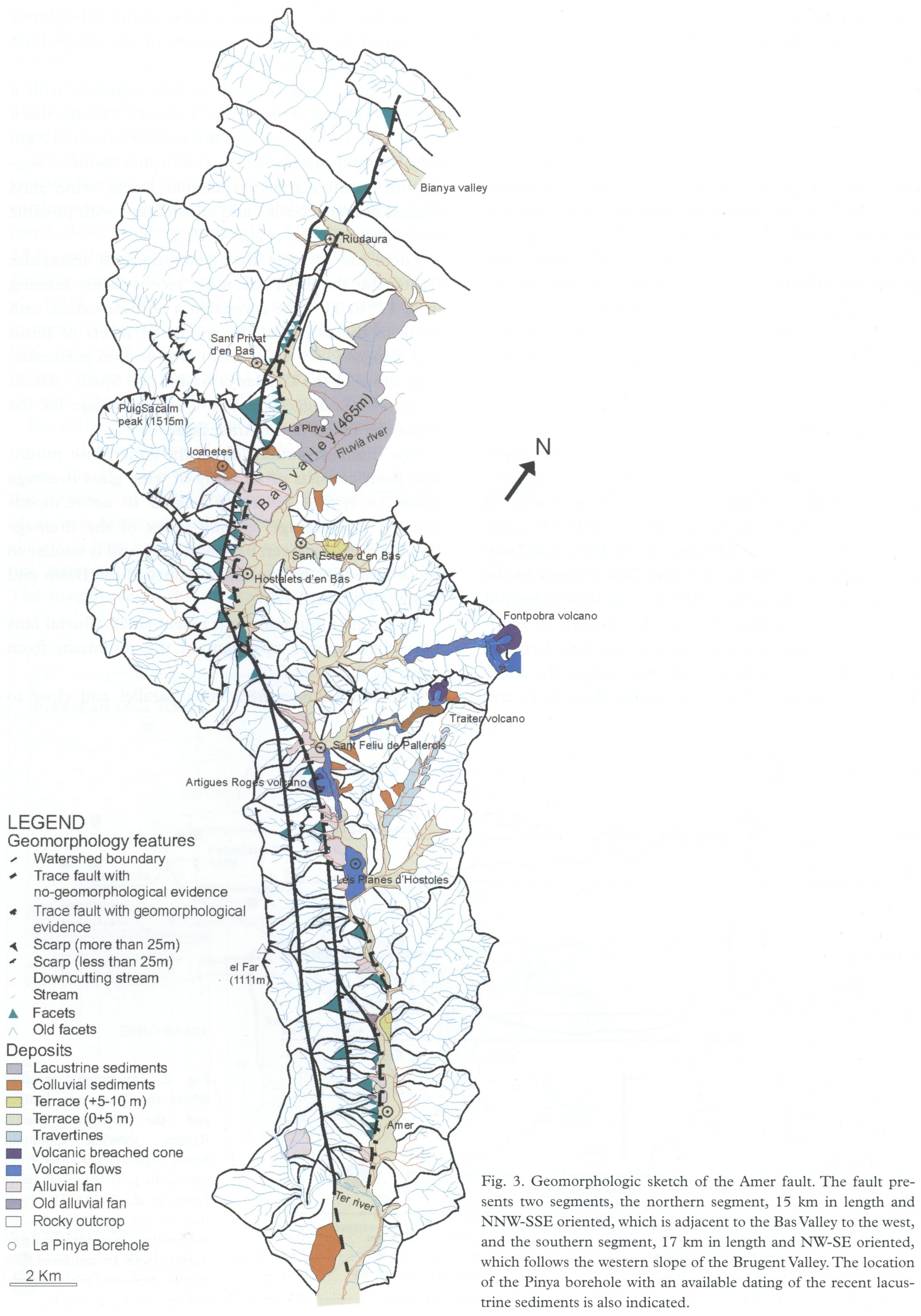




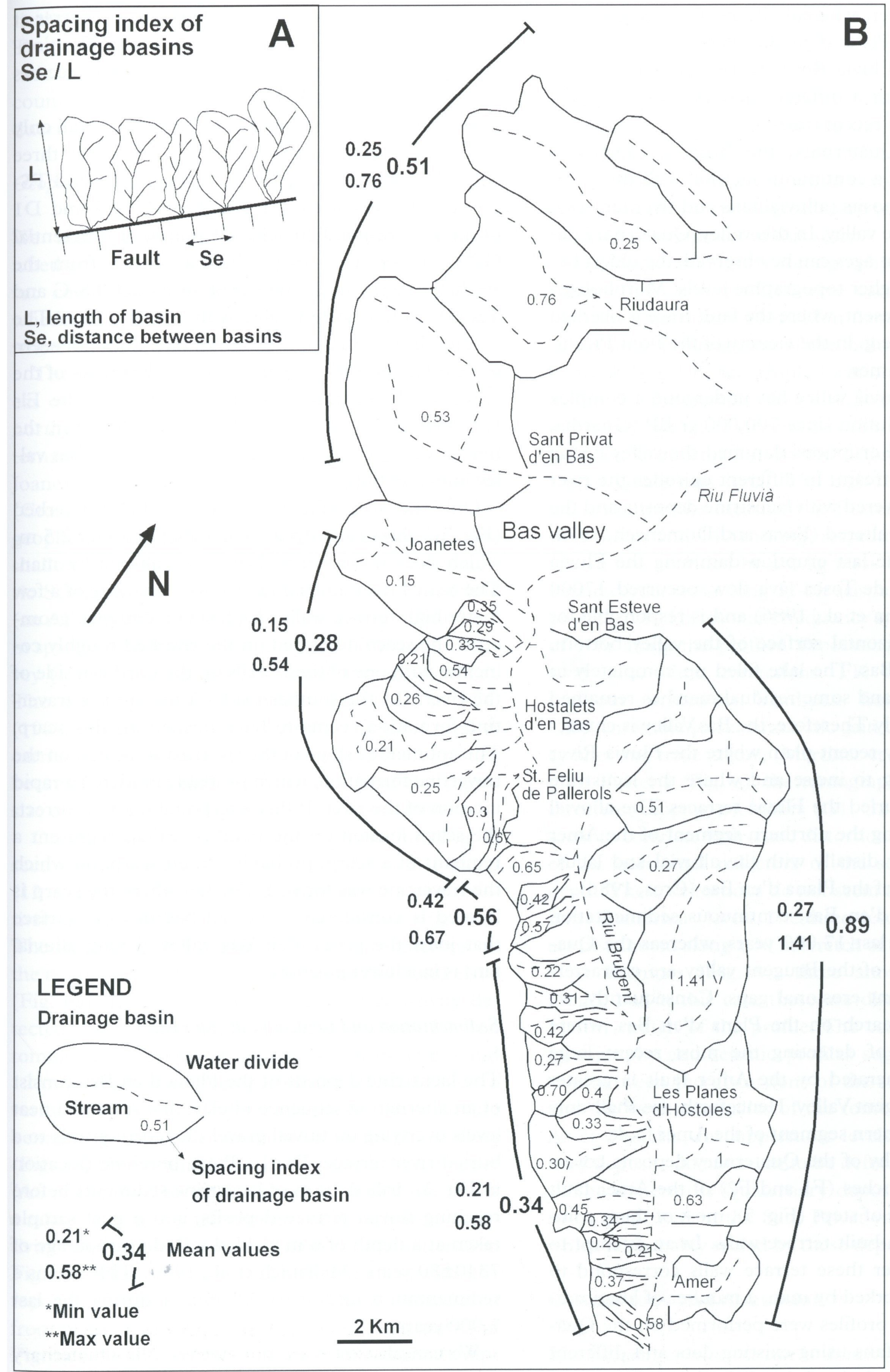

Fig. 4. Drainage basins along the Amer fault. A. Parameters used in the study of the spacing index of drainage basins. B. Drainage basins related to the Amer fault. The spacing index of the drainage basins formed on the active mountain front varies between 0.28 and 0.56 (between 0.25 and 0.55 on the active mountain fronts of Basin and Range, Wallace 1978). The size and shape of the basins north of Joanetes (higher spacing index) are controlled by folding structures, whereas the southern drainage basins formed on a tabular relief. 
the Brugent River, whereas the northern segment is adjacent to the Plana d'en Bas (Bas Plain), which is crossed by the Fluvià River, to the west. These two valleys underwent a different geologic and geomorphic evolution in recent times.

During the Quaternary, the Brugent valley was characterized by a continuous incision with the result that terraced deposits (alluvial fans and river terraces) formed along the valley. In this valley, Quaternary deposits of different ages can be observed, the oldest being located at higher topographic levels. Morphological scarps are present, where the fault trace is overlain by alluvial fans, e.g. in the vicinity of the Font Picant, to the north of Amer.

The upper Fluvià valley has undergone a complex geomorphic evolution since 700,000 yr BP (Guardia, 1964). Repeated eruptions dammed the valley giving rise to lakes upstream. In different episodes the river terraces were covered with lacustrine deposits and the river profile was altered (Fayas and Doménech, 1974; Cros, 1986). The last eruption damming the Fluvià River, the Bosc de Tosca lava flow, occurred 17000 years ago (Guérin et al., 1986) and is responsible for the present horizontal surface of the valley bottom, the Plana d'en Bas. The lake filled up completely in historical times and some residual marshes remained until very recently. Therefore, the Bas Valley is characterized by a very recent plain where the Fluvià River is just beginning to incise and where the lacustrine deposits have buried the Fluvià terraces. The alluvial fans formed along the northern segment of the Amer fault, interfinger distally with the alluvial and lacustrine sediments of the Plana d'en Bas (Cros, 1986).

In the Plana d'en Bas, continuous sedimentation occurred in the last 17,000 years, whereas the Quaternary deposits of the Brugent valley are characterized by important erosional gaps. Consequently, we focused our research on the Plana d'en Bas, where the probability of detecting the most recent large earthquakes generated by the Amer fault is greater than in the Brugent Valley. Henceforth, we shall only refer to the northern segment of the Amer fault.

The topography of the Quaternary deposits covering the two branches (F1 and F2) of the Amer fault shows a number of steps (Fig. 5), most of them coinciding with man-built terrace-walls. In an attempt to ascertain whether these terrace walls correspond to fault scarps reworked by man, a number of longitudinal topographic profiles were performed on the Quaternary alluvial fans using existing data and different techniques: i) analysis of the digital elevation model of Catalunya (15x15m) (ICC, 1999b); ii) analysis of a digital elevation model $(10 \times 10 \mathrm{~m})$, a specially ordered topographic restoration of about $235 \mathrm{Ha}$ (SYSIGSA,
1999); iii) profile leveling with total station (Ferrer et al., 1999b), and iv) two Differential Global Positioning System surveys (Estruch, 1999). Four sectors were investigated (A, B, C and D in Fig. 5).

When presenting the results obtained, we shall only report on five topographic profiles located at three sites: Sant Privat (A8 profile), Joanetes (C5 and TSC) and els Hostalets (D1 and TS-D1). C5 and D1 profiles correspond to selected points of differential GPS surveys. The A8 profile was drawn from the available $10 \times 10 \mathrm{~m}$ digital elevation model. TS-C and TS-D1 profiles were leveled with a total station. The longitudinal profile of the alluvial fans does not seem to be offset by a recent slip of the two branches of the fault, as demonstrated by the examples of the Els Hostalets and Joanetes fans (Fig. 5b). Moreover, the fan surfaces join the horizontal surface of the Bas valley imperceptibly.

Only the A8 profile along the Sant Privat riverbed (Fig. 5c) shows a scarp with an offset of about $2.5 \mathrm{~m}$, which does not seem to have been altered by man. The Sant Privat alluvial fan shows a number of a few meter high terrace walls, displaying a complex geometry. The scarp described on the riverbed roughly coincides with one of these walls on the northern side of the river. On the southern side of the river, a travertine formation seems to have formed on this scarp. The anomalous slope of the riverbed is located on the travertine formation, which probably hindered a rapid incision of the river. If this interpretation was correct, the scarp located on the riverbed would represent a remnant of a scarp, probably a fault scarp, on which the travertine was formed. The fan where the scarp is located is considered to be old because the surface that joins the plana d'en Bas valley (young alluvial fan) is in a lower position.

\section{Sedimentation and vertical fault slip rates}

The lacustrine deposits of the Plana d'en Bas consist of an alternating sequence of clay, fine sand and peat levels overlying on fluvial gravel that corresponds to a buried river terrace. The La Pinya borehole (location in Fig. 3) drilled $10 \mathrm{~m}$ of lacustrine sediments before reaching fluvial terrace deposits, and a peat sample taken at a depth of $6 \mathrm{~m}$ yielded a Radiocarbon age of $7340 \pm 80$ years (Mallarach et al., 1986). This means a sedimentation rate of ca $0.8 \mathrm{~mm} / \mathrm{yr}$ during the last 7,000 years.

We can also estimate the average Plio-Quaternary rate of vertical slip of the Amer fault from the height of the most recent triangular facets. The offset of the facets is approx $250 \mathrm{~m}$ (Ferrer et al., 1999), and assuming 5-2 My for this period we can estimate a ver- 
tical slip-rate ranging between 0.05 and $0.125 \mathrm{~mm} / \mathrm{yr}$. The sedimentation rate is nearly one order of magnitude greater than the fault slip rate. This could account for the absence of morphological scarps produced by fault activity on the most recent sediments.

\section{Geophysical studies}

We used geophysical techniques to i) investigate whether the scarp detected in the vicinity of Sant Privat could be caused by the Amer fault, and ii) whether this fault cuts through Quaternary sediments where scarps are absent as in the Joanetes valley.

The geophysical survey was carried out in two areas of the western slope of the Bas valley where the northern segment of the Amer fault crosses two Quaternary alluvial fans (sectors of Sant Privat, A, and Joanetes, C in Fig. 5). Two earlier geophysical surveys (Cros, 1986; SGC, 1998) were considered. Three geophysical devices were used to characterize the shallow Quaternary levels: i) electric logs (a symmetric Schlumberger device); ii) a dipole-dipole method (an $\mathrm{AB}$ and $\mathrm{MN}$ device of $4 \mathrm{~m}$ on the ground and a 2 $\mathrm{m}$ spacing grid in cross section), and iii) a seismic survey ( $1 \mathrm{~m}$ of spacing and 45 sensor stations by shot). The works performed are fully described in ICC (1999c) and Martínez et al. (2000). The GPR profiles carried out in these sectors did not yield useful results because of to the high water content and the coarse size of the materials (Gourgot and Molas, 1999).

On the Sant Privat Quaternary alluvial fan (Fig. 5, sector A, geo-electric profile I-I') electrical logging (12 electrical logs) provided evidence of some resistivity anomalies by a high lateral contrast (Fig. 6a). The trace of fault $\mathrm{F} 2$ deduced from the outcrops on the nearby bedrock is located between el-17 and el-16 (Fig. 6a). The high lateral contrast of resistivity detected could, therefore, be produced by fault F2. Ten tomography sections of approx $100 \mathrm{~m}$ in length and $12 \mathrm{~m}$ in depth have been performed (ICC, 1999c) to verify this anomaly and to investigate the structure beneath the scarp detected by topographic leveling (Fig. 5c). We obtained the best results at Mas Soques (A6 in Fig. 5). The profile obtained at this site shows a relatively high electric contrast of the apparent resistivity values following an east-dipping line (letter $G$ in Fig. 7). This anomaly roughly coincides with the topographic scarp and the trace of fault $\mathrm{F} 1$ deduced from bedrock outcrops (F1 in Fig. 5, and s and G in Fig. 6a). On the right side of the profile, a gently dipping electric contrast (non labeled arrow) could correspond to a stratigraphical discontinuity such as the erosion surface overlain by coarse conglomarates observed in the neighboring outcrops. However, the steep dipping electrical contrast, G, (Fig.7) may correspond to a fault, indicating that faulting affects shallow Quaternary beds.

This suggests that in the Sant Privat valley, fault F1 reaches the topographic surface through the Quaternary deposits. The scarp south of Mas Soques, which is modified by agriculture, could correspond to a fault scarp, and the morphological scarp on the Sant Privat riverbed to a remnant of this scarp.

Ten electrical logs, 5 tomography sections and 2 seismic reflection profiles were carried out on the Joanetes Quaternary alluvial fan (zone C, Fig. 5), exactly on the prolongation of the faults observed in the bedrock (Fig. 6b, see profile location in II-II' profile in Fig. 5). Tomography and seismic reflection profiles at the Fusteria and Estruços sites (S1 and S2 in Fig. 5) yield some information on the deformation affecting Upper Quaternary levels. The high-resolution seismic reflection profiles measured at Fusteria and Estruços were $72 \mathrm{~m}$ and $140 \mathrm{~m}$ long, respectively. The energy source was provided by a $8 \mathrm{~kg}$ mass hammer and the data recorder was a long 32-bit seismograph with geophones of $40 \mathrm{~Hz}$ resonant frequency spaced at intervals of $1 \mathrm{~m}$ along the profiles. Processing included walkaway test, static corrections, FK filtering, normal moveout corrections, band-pass frequency filtering, $\mathrm{CDP} /$ ensemble stack, automatic gain control, coherency filter and trace mixing (Martínez et al., 2000).

At Fusteria (Fig. 8), the tomography profile shows three east-dipping anomalies (G1, G2 and G3), which seem to correlate with some distortions (g1, g2 and g3) of the horizontal reflectors of the seismic profile at depth. These distortions do not seem to cut the uppermost Quaternary levels. The three described anomalies are distributed along a $30 \mathrm{~m}$ stretch of the profile.

At Estruços (Fig. 9), three anomalies are also found, but in this case these are distributed along a $100 \mathrm{~m}$ stretch of the profile. The comparison of the tomography and seismic profiles suggests a correlation between the distortions of the seismic reflectors and the weak anomalies of the tomograpphy profile. As at Fusteria, the uppermost levels of the Quaternary deposits do not seem to be deformed.

The uppermost Quaternary deposits do not seem to be deformed in the Sant Privat valley by fault F1 which is probably sealed by these deposits.

\section{Conclusions and discussion}

\section{The following conclusions can be drawn}

No evidence of surface deformation was found at sites where the topographic surface is formed by very recent deposits (Holocene). This is the case of the 


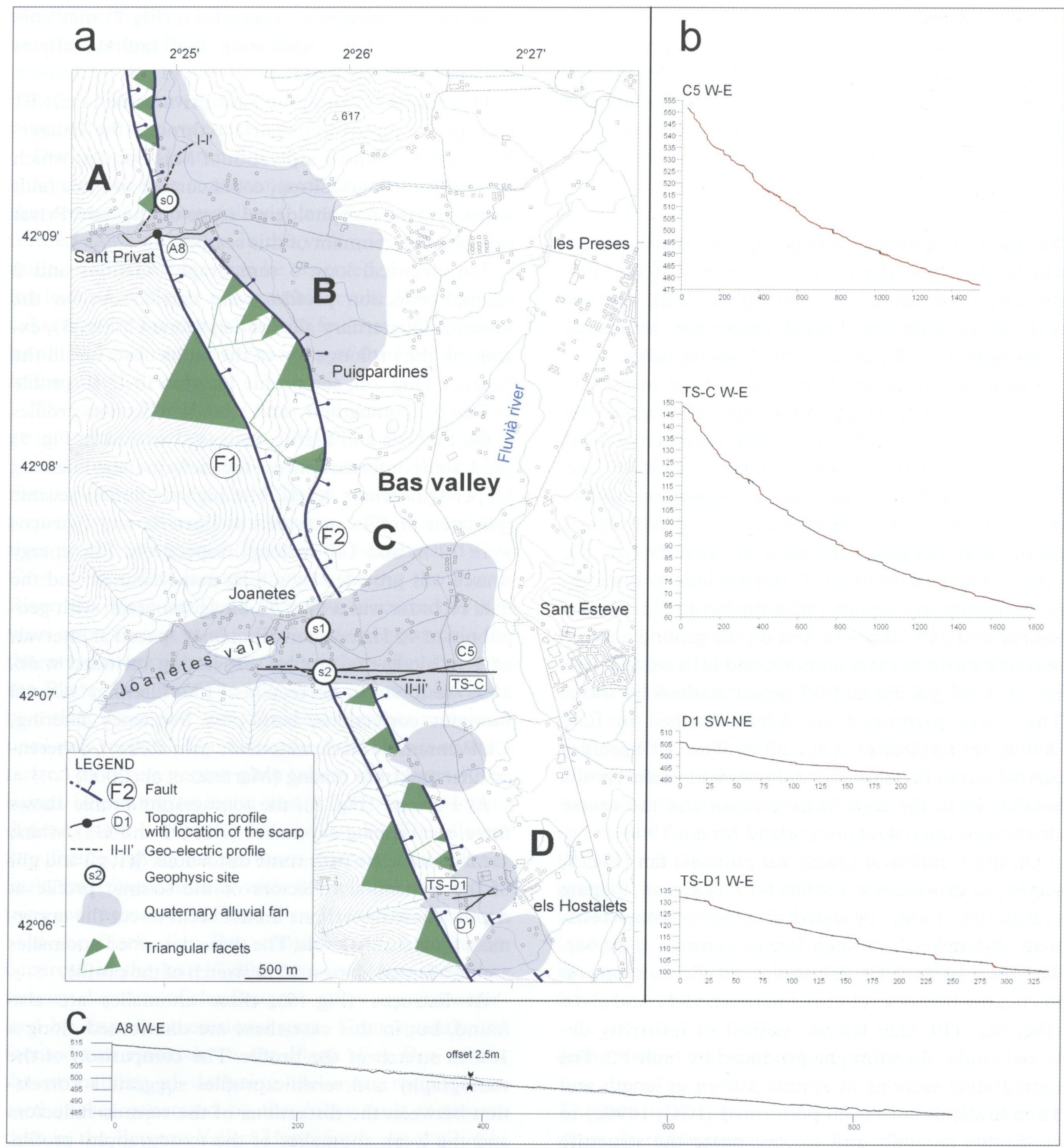

Fig. 5. Topographic profiles across the Amer fault in the Bas valley. a) Map showing Quaternary alluvial fans, triangular facets, trace of the faults and the location of topographic, geo-electric, seismic and tomographic profiles. The sectors studied are indicated by A, B, C and D. b) Topographic profiles C5, TS-C, D1 and TS-D2 without natural scarps. c) A8 topographic profile along the riverbed of Sant Privat showing a natural scarp of $2.5 \mathrm{~m}$ offset.

Joanetes and the Els Hostalets alluvial fans whose surfaces imperceptibly join the horizontal Plana d'en Bas topographic surface.

Scarps interpreted as fault scarps produced by the Amer fault were only observed on old alluvial fans, probably Pleistocene in age. The scarp in the Sant Privat valley constitutes such an example.

Tomography and seismic profiles suggest that de- formation related to the Amer fault reaches Quaternary levels, although this does not affect the uppermost horizons. The profiles performed at Fusteria and Estruços illustrate this feature.

\section{Discussion}

Since the Amer fault provides geomorphologic evi- 
A) SW-NE Profile I-I'

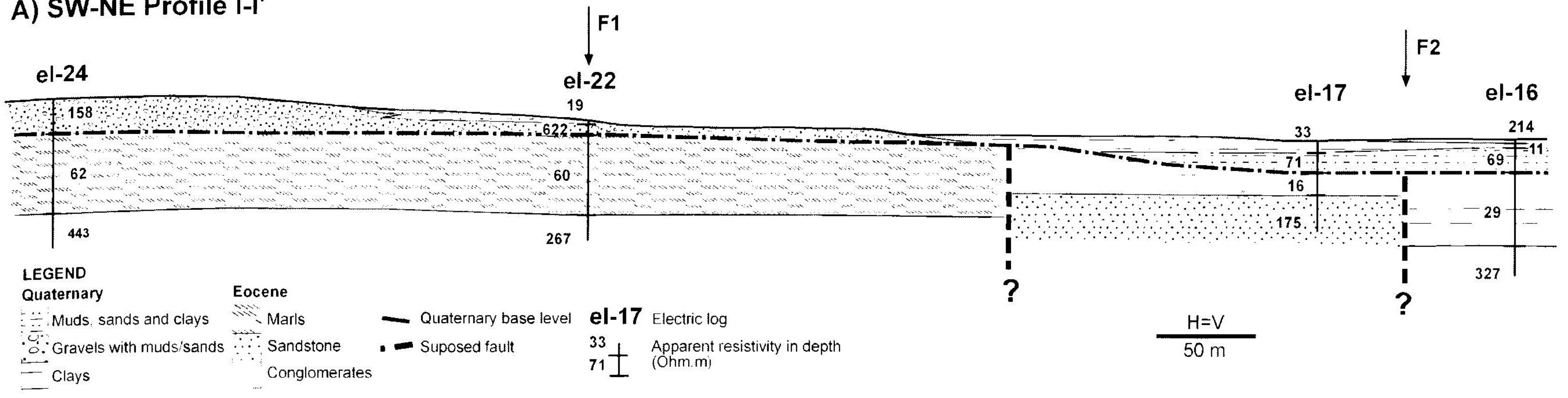

B) W-E Profile II-II'

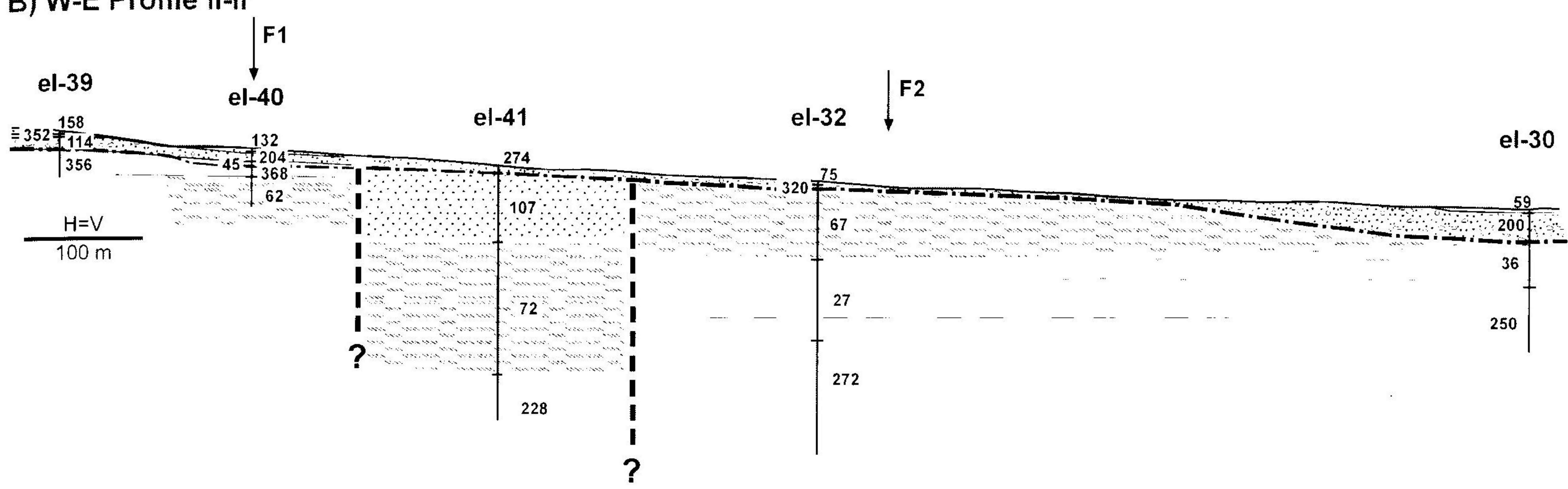

Fig. 6. Geo-electric profiles of the Bas Valley. a) Sant Privat area (sector A in Fig. 5). The measured apparent resistivity in depth indicates two major anomalies between el-22 and el-16 logs that might be related to faults F1 and F2 indicated by '?', whose location is shown in Fig. 5. b) Geo-electric profile of the Joanetes area (zone B in Fig. 5). From the measured apparent resistivity in depth we can deduce two major anomalies between el- 40 and el-32 logs that might be related to faults F1 and F2 indicated by '?'whose location is shown in Fig. 5.

dence of homogeneous behavior along its entire length, it is reasonable to assume that the maximum expected earthquakes could be caused by the rupture of each of the segments (approx $15 \mathrm{~km}$ ), or by the rupture of the entire fault (approx $30 \mathrm{~km}$ ). These earthquakes would be larger than the historical ones, and, in accordance with the data published by Wells and Coppersmith (1994), would have magnitudes of ca 6.5 and between 6.5-7 respectively. Earthquakes of such magnitudes would form scarps of $0.5 \mathrm{~m}$ and $1 \mathrm{~m}$ in height, and could be investigated by means of paleoseismological techniques in trenches. However no scarps are present at sites with recent continuous sedimentation.

The absence of scarps can be explained by considering the magnitude of the different parameters involved. Scarps of $0.5 \mathrm{~m}$ to $1 \mathrm{~m}$ in height would be totally buried after 625 to 1250 years of deposition giv- en a sedimentation rate of $0.8 \mathrm{~mm} / \mathrm{yr}$. The average recurrence interval for events producing scarps of $0.5 \mathrm{~m}$ would range between 4,000 and 10,000 years if we consider vertical slip-rates varying between 0.05 and $0.125 \mathrm{~mm} / \mathrm{yr}$ as previously estimated. With the same slip-rates, the average recurrence intervals for the formation of $1 \mathrm{~m}$ high scarps would range between 8,000 and 20,000 years. Thus, the estimated recurrence intervals are 4 to 20 times greater than the time required for burying the scarps.

A near fault paleoseismic investigation requires trenching across the fault and to detect and analyze the geological record (buried scarp associated with colluvial wedge, for ex.) of past large earthquakes, preferably the most recent ones. The record of the 1427 earthquakes on the surface must have been very weak because of its magnitude. If this record had existed it would probably have been destroyed by farm-

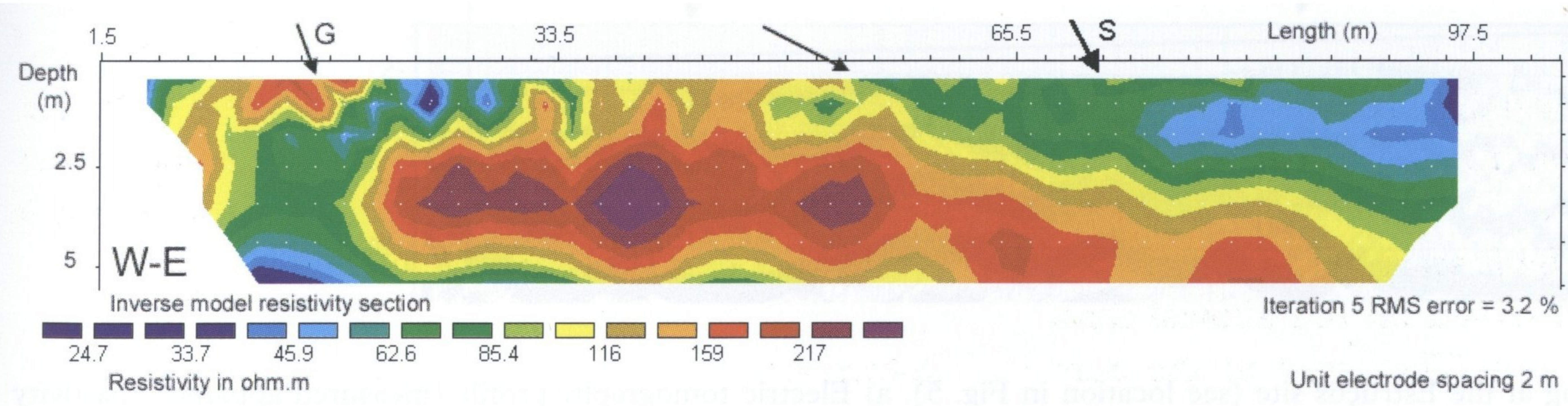

Fig. 7. Tomography profile at Mas Soques. High electric contrasts shown by arrow G can be related to the presence of surface ruptures. The arrow without label can be related to a stratigraphic discontinuity. This profile is not topographically corrected. 


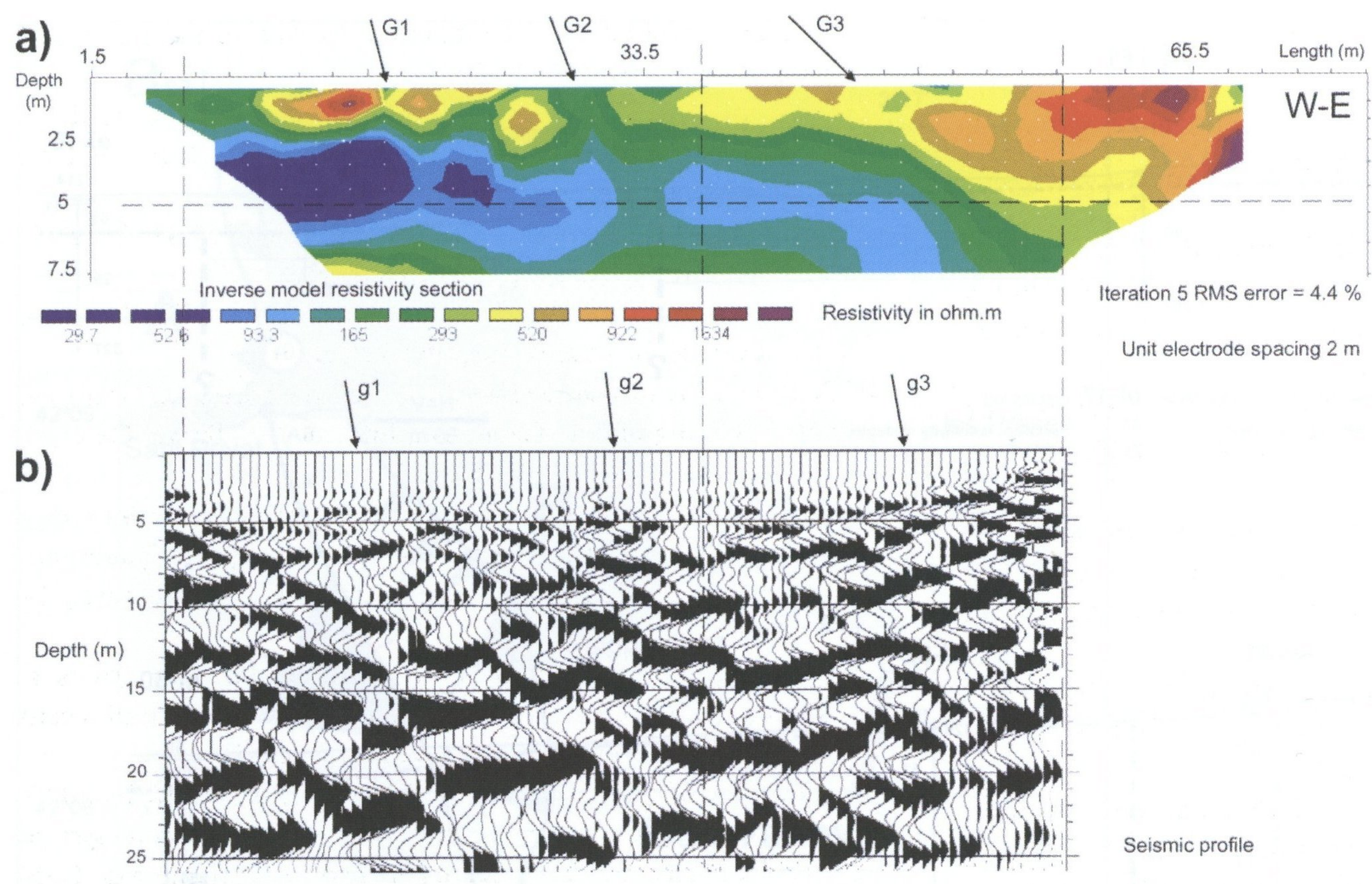

Fig. 8. Geophysical prospecting at the Fusteria site (see location in Fig. 5). a) Electric tomography profile (Inverse model resistivity section), and $b$ ) seismic profile. Arrows ( $\mathrm{G}$ for the electric tomography profile and $\mathrm{g}$ for the seismic profile) indicate lateral anomalies, which can be correlated with both profiles. Reflectors located deeper than $10 \mathrm{~m}$ are clearly distorted (i.e. g1 case, in b), but uppermost Quaternary levels are not.

ing, which has taken place since the Middle Ages. The geological record of the most recent large earthquakes should be found along the northern segment of the fault, where the damming of the Fluvià valley by a lava flow 17,000 years ago led to a continuous sedimentation. However, the maximum depth of a trench is an important limitation given the sedimentation rates involved. It is probable that a trench reaches only the sediments deposited after the last large earthquake, and does not reach the fault. Trenching across scarps on old alluvial fans (southern segment and the Sant Privat valley in the northern segment) can yield insights into the previous activity of the fault.

\section{Acknowledgements}

The research was supported by the Paleosis project (ENV4-CT97-0578 EC). We thank P. Ferrer (Universitat de Barcelona) for geomorphologic analysis of the Amer fault; F. Renardy (University of Liege) for the inversion process in tomography profiles of the Amer fault and $M$. Calvet (Université de Perpignan) for field discussions. We also thank all the members of the Paleosis project for fruitful discussions during the fieldtrips. We are grateful to the reviewers for their useful comments and suggestions.

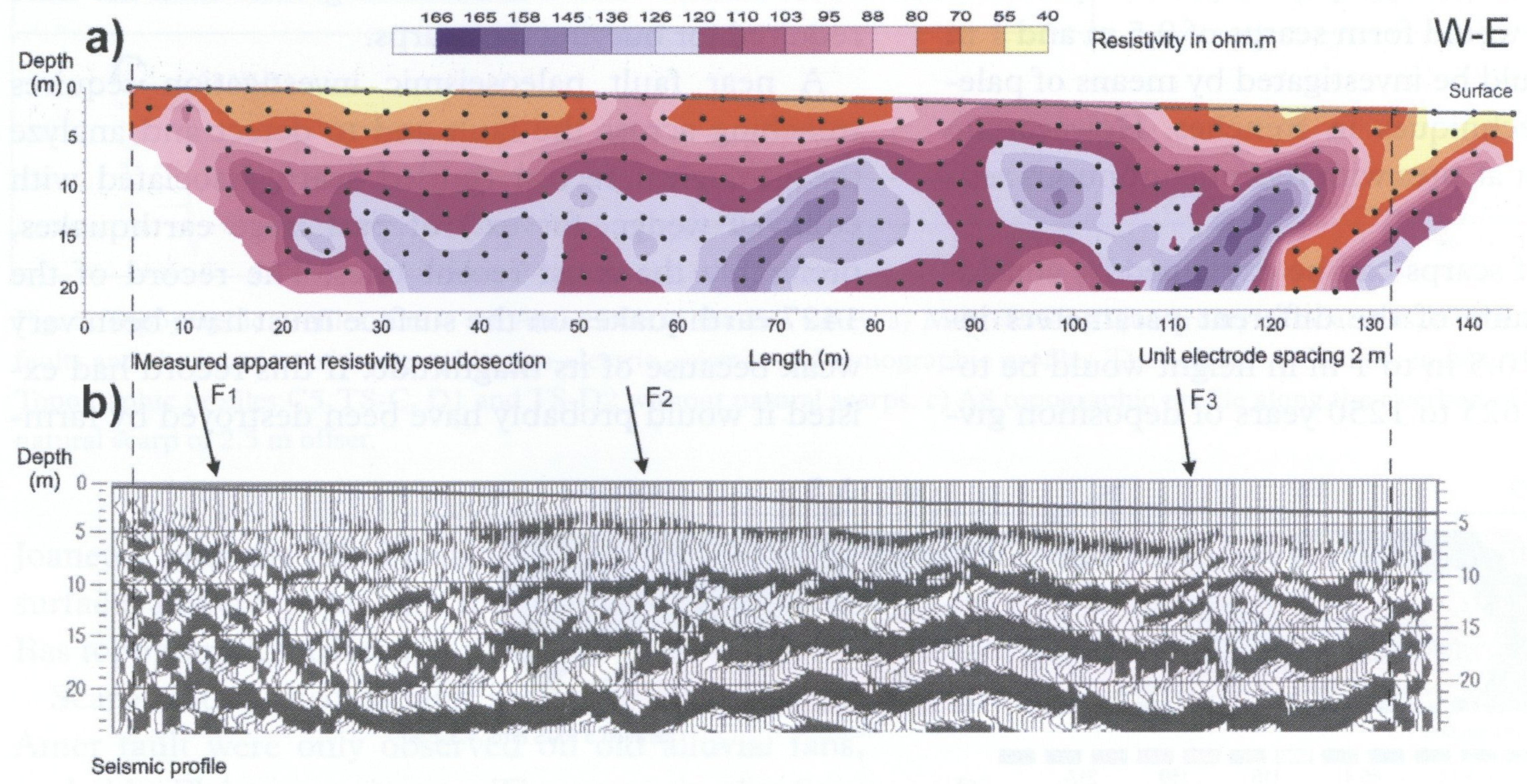

Fig. 9. Geophysical prospecting at the Estruços site (see location in Fig. 5). a) Electric tomography profile (measured apparent resistivity pseudosection), and b) seismic profile. The anomalies in the tomography pseudo-section profile can be related to small contrasts of the higher resistivity values. These contrasts can be correlated with distortions of the horizontal reflectors in the seismic profile (F1, F2 and F3). 


\section{References}

Barnolas, A., Saula, E., Mató, E., Muñoz, J.A. and Escuer, J., 1994. Mapa Geológico de España E 1:50.000 294 Manlleu. 51 pp., ITGE.

Briais, A., Armijo, R., Winter, T., Tapponnier, P. \& Herbecq, A., 1990. Morphological evidence for Quaternary normal faulting and seismic hazard in the Eastern Pyrenees. Annales Tectonicae, Vol. IV (1): 19-42.

Cros, J., 1986. El Quaternari de la Vall d'en Bas (província de Girona). Tesis de Llicenciatura, Universitat Autònoma de Barcelona, 62 pp.

Estruch, I., 1999. Estudi de les anomalies topogràfiques en relació a l'activitat tectònica recent a la falla d'Amer-Brugent (Vall d'en Bas). Institut Cartográfic de Catalunya, Informes del Servei Geològic de Catalunya, GS123-99, 132p., 5 anexes.

FAUST, 2001. FAUST [on line]: http://faust.ingv.it, 20.04.2001.

Fayas, J.A., \& Doménech, J., 1974. Morfología volcánica de Olot y su interés hidrológico. Agua, 85: 20-31.

Ferrer, P., Masana, E. \& Santanach, P., 1999a. Expresión geomorfológica de la actividad reciente de la falla de Amer (NE de la Península Ibérica). Acta Geol. Hispànica, 31 (1996), 4: 17-24 (Pub. 1999).

Ferrer, P., Masana, E. \& Santanach, P., 1999b. Analysis of relevant geologic and geomorphologic data for paleoseismologic trenching across the Brugent fault. Paleosis, Internal report, Institut Cartogràfic de Catalunya, $25 \mathrm{pp}$.

Fleta, J., \& Goula, X., 1998. Paleosis Region IV: Eastern Pyrenees. Internet, http: //www.astro.oma.be/PALEOSIS/epyr/index4.htm.

Fleta, J., Goula, X., Grellet, B., Estruch, I., Palomera, R., Martínez, P., Teixidó, T., Masana, E., Ferrer P. \& Santanach, P., 1999. Technical report on the activity for the period March 1998 February 1999. Investigations in the Eastern Pyrenees. Institut Cartogràfic de Catalunya. Paleosis-project (ENV4-CT97-0578) March 1999 report, partner 6, GC.DPT.ICC, 40-72.

Giménez, J., Suriñach, E., Goula, X. and Fleta, J., 1996. Recent vertical movements from precise levelling data in the Northeast of Spain. Tectonophysics, Vol. 263 (1-4): 149-162

Goula, X., Talaya, J., Tèrmens, A., Colomina, I., Fleta, J., Grellet, B. and Granier, Th., 1996. Avaluació de la potencialitat sísmica del Pirineu Oriental: Primers resultats de les campanyes GPS PotSis'92 i PotSis'94. Terra, 28: 41-48.

Goula, X., Olivera, C., Fleta, J., Grellet, B., Lindo, R., Rivera, L.A.; Cisternas, A. \& Carbon, D., 1999. Present and recent stress regime in the eastern part of the Pyrenees. Tectonophysics, 308 (4): 487-502.

Gourgot, S. \& Molas, L., 1999. Paleosis GPR survey. Sector of Olot - Spain. Report 99.201 v1.1. Institut Cartogràfic de Catalunya. $41 \mathrm{pp}$.

Guérin, G., Benhamou, G. \& Mallarach, J.M. 1986. Un exemple de fusió parcial en medi continental. El vulcanisme quaternari de Catalunya. Vitrina, 1:20-26.

Guardia, M.P., 1960. Contribution à l'étude des volcans de la province de Gerone et du paléomagnetisme de leurs coulées. Thèse, Université de Paris, 56 pp.

ICC, 1999a. Mapa de sismicitat de Catalunya 1977-1997 Escala 1:400 000. Institut Cartogràfic de Catalunya.

ICC, 1999b. Base de dades altimètrica de Catalunya BD-MET15. Computer file. Institut Cartogràfic de Catalunya.

ICC, 1999c. Prospecció geofísica a la Vall d'en Bas. La Garrotxa. Institut Cartográfic de Catalunya, Informes del Servei Geològic de Catalunya, GA-157/99, 32 pp., 5 annexes.

Lewis, C.J., Vergés, J. \& Marzo, M., 2000. High mountains in a zone of extended crust: Insights into the Neogene-Quaternary topographic development of northeastern Iberia. Tectonics, 19 (1): 86-102.

Mallarach, J.M., Pérez, R. \& Roure, J.M., 1986. Aportacions al coneixement del clima i la vegetació durant el Quaternari recent en el NE de la península Ibèrica. Vitrina, 1: 49-54.

Martínez, P., Teixidó, T., Fleta, J., Goula, X. \& Renardy, F., 2000. Geophysical prospection at the Amer-Brugent fault system (Girona, Spain). Procs. II Asamblea Hispanoportuguesa de Geodesia y Geofisica, S03-13, 135-136.

Olivera, C., Redondo, E., Riera, A., Lambert, J. \& Roca, A., 1999. Problems in assessing focal parameters to earthquake sequences from historical investigation: The 1427 earthquakes in Catalonia. Procs. IX Asamblea Española de Geodesia y Geofísica, SIM207, $8 \mathrm{pp}$.

PALEOSIS, 1999. PALEOSIS [on line]: http://www.astro.oma.be/PALEOSIS/, 4.05.1999.

Saula, E., Picart, J., Mató, E., Llenas, M., Losantos, M., Beràstegui, X. \& Agustí, J., 1996. Evolución geodinámica de la fosa del Empordà y las Sierras Transversales. Acta Geol. Hispànica, 29 (1994): 55-75.

SGC, 1998. Inventari de pous de Catalunya. Servei Geològic de Catalunya, Computer file.

SYSIGSA, 1999. Projecte Paleosis, Restitució fotogramètrica i malla tridimensional del terreny de $10 \mathrm{~m}$. Zones: Sant Privat $\mathrm{i}$ Joanetes. Computer file. Institut Cartogràfic de Catalunya.

Talaya, J., Feigl, K., Térmens, A. \& Colomina, I., 1999. Practical lessons from analysis of a GPS network designed to detect movements of $1 \mathrm{~mm} / \mathrm{year}$ in the Eastern Pyrenees. Phys. Chem. Earth (A), Vol. 24 (4): 355-359.

Wallace, R.E., 1978. Geometry and rates of change of fault generated range fronts, North-Central Nevada. Jour. Res. U.S. Geol. Surv., 6(5): 637-649.

Wells, D.L. \& Coppersmith, K.J., 1994. New empirical relationships among magnitude, rupture, length, rupture wide, rupture area and surface displacement. Bull. Seismological Soc. Am., 84 (4): $974-1002$ 